\title{
INTERVENTION BY PUBLIC AGENCIES IN PRIVATE LITIGATION IN THE FEDERAL COURTS
}

\author{
BY RAOUL BERGER $\dagger$
}

Intervention in a private suit has as its fundamental purpose the prevention of injury which may result from a proceeding unless the party who is attempting to intervene is heard. ' The basic problem of intervention practice is the adjustment between the need for such protection and the traditional view that a law suit is a private controversy in which outsiders have no place. In meeting the problem, the courts have set up two categories of intervention. Where an applicant for intervention has had some other remedy for the satisfaction of his grievance, he has been permitted to intervene ${ }^{2}$ if trial convenience allowed. Permissive intervention has thus enabled the court to balance the litigant's right to have his dispute settled with a minimum of interference against the factors which might recommend intervention in the particular case. ${ }^{3}$ Where, however, other remedies have been absent and a denial of intervention would have resulted in irremediable injury, considerations of the litigants' convenience have yielded to the intervener's need for protection and the right of intervention has been regarded as absolute.

$\dagger$ Mfember of the District of Columbia bar.

1. See Florida v. Georgia, 17 How. 478,493 (U. S. 1854); Krippendorf v. Hyde, 110 U. S. 276, 283 (1884) ; 2 MLoore's Federal Practice (1938) 2315, 2316; 3 Ontu:ger's Federai Practice (1939) 374.

2. See notes $54,69,71$ infra.

3. Compare FED. Rules Crv. Proc. 24(b) (2) : “. . . In exercising its discretion the court shall consider whether the intervention will unduly delay or prejudice the adjudication of the rights of the original parties."

4. The wording of Fed. Rules Crv. Proc. 24 has broken away from the traditional tests for absolute and permissive intervention. See pp. 75, 84 infro. Mloore \& Levi, Federal Intervention (1936) 45 Y.ALE L. J. 565, 582, believe that the absolute right should not depend on the non-existence of other means of redress. In discussing the cases involving an interest in property in control of the court they point out that "since a third person's rights are apt to be seriously jeopardized in all these cases, and may be cut off in some, the remedy of intervention is clearly necessary to prevent the court's processes from injuring his rights." The writer agrees that the non-existence of another remedy should not be the sole test of the absolute right, but that the efficacy of another remody; where it exists, should be weighed and consideration given to the siturtion in which sonc injury may result, despite the presence of another remedy, if intervention is barred. Compare United States v. Radice, 40 F. (2d) 445 (C. C. A. 2d, 1930). But since Moore and Levi attribute the expansion of intervention practice to the courts' desire to prevent their process from injuring third persons (Moore \& Levi, supra at 573) and state that the "development began where injury was most likely to occur" (ibid.), it seems that this principle should not be limited to cases involving an interest in property in ctustodia legis. It seems rather to extend to all cases in which the applicant's interests are "seriously" jcopardized." Compare notes 70 and 72 infra. 
If the foundation of intervention practice is the prevention of injury, it seems that the right of intervention should logically be extended to federal and state governments wherever harm is threatened to the "public interest." The logic of thus extending to governmental agencies the right "to intervene in suits between private parties to protect a public interest" is confirmed by the cases. "Logic and precedent have been somewhat blurred, however, by recent events. Most important of these is the restatement of intervention practice in Rule 24 of the Federal Rules of Civil Procedure in terms that unfortunately lend themselves to the argument that the government cannot intervene except where explicit statutory authorization exists. This argument has been somewhat stilled with respect to the "permissive" branch of the rule in the recent case of Securities \& Exchange Commission \%. United States Realty \& Improvement $C_{0 .}{ }^{6}$ in which a divided Supreme Court held that the SEC might be permitted to intervene in a proceeding under Chapter XI of the Bankruptcy Act. But the Court shed little light on the problems of construction raised by the permissive intervention section of the Rule, ${ }^{7}$ and it has already been suggested that the decision may be limited to intervention in a bankruptcy proceeding. ${ }^{8}$ The Court, moreover, found it unnecessary to disturb the Second Circuit Court's decision in the case below that the SEC had no absolute right to intervene in the absence of statutory authority or a right to possession or control of specific property involved in the litigation. The application of the Rule is further complicated by the Act of August 24, 1937, which confers on the Federal Government an absolute right to intervene in private litigation that challenges the constitutionality of federal legislation. ${ }^{0}$ This legislation raises a doubt whether the right of absolute intervention exists in the absence of statutory authorization and poses for refutation the argument that by limiting inter-

5. Rocca v. Thompson, 223 U. S. 317,330 (1912); see also Florida v. Georgia, 17 How. 478 (U. S. 1854) ; The Exchange v. M'Faddon, 7 Cranch 116 (U. S. 1812) ; Pennsylvania v. Williams, 294 U. S. 176 (1935); Securities \& Exch. Comm. v. United States Realty \& Imp. Co., 310 U. S. 434 (1940).

6. 310 U. S. 434 (1940) (hereinafter termed the Realty case).

7. See p. 75 infra.

8. See 3 Fed. Rules Serv. Comim. 24 b. $2-2$.

9. 50 Stat. 751 (1937), 28 U. S. C. $\$ 401$ (Supp. 1937). Compare Burco, Inc. v. Whitworth, 81 F. (2d) 721 (C. C. A. 4th, 1936), and adverse comments thercon in Congress, 81 Cong. Rec. 3271-3272 (1937); see also Chicago \& Grand Trunk Ry. v. Wellman, 143 U. S. 339, 344, 345 (1892).

Congress has recently sought to extend to state agencies the right to intervenc in a somewhat similar situation. H. R. 7737 was passed by Congress, vetoed by the President, and repassed, but only by the House of Representatives. See 86 Cong. Rec., Aug. 5 , 1940, at 15074. The bill enables a state to intervene as a matter of right whenever the validity of any federal action is questioned, if (1) the determination of such question should involve any conflict with the exercise of any governmental power of such statc, or (2) such federal action would impair any governmental power asserted or excreised by such state or agency thereof. 
vention of right to a specific situation, Congress showed an intent to exclude the right in all other circumstances.

It is the purpose of this Article to examine governmental intervention in the light of these events and of administrative needs. The importance of the interests involved is underscored by the 1937 Act. This legislation arose from a realization that the constitutionality of a statute which affects the economic and social interests of millions should not be left to the hazards of private combat, that the public has a vital stake in the issue, and that the courts may be better informed as a result of

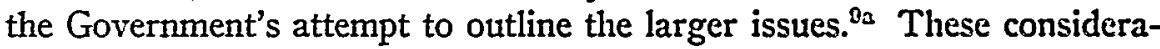
tions, however, may be no less urgent where private litigation involves a particular application rather than the validity of federal legislation. As is strikingly illustrated by the above-mentioned Realty case, a regulatory scheme designed to cure notorious abuses may be as effectively prejudiced by the way a statute is construed in a private suit as by a declaration of its constitutional invalidity. An agency's right to protest against an impairment of administrative functions likely to result from an incautious assumption of jurisdiction by the courts has long been recognized. ${ }^{10}$ And intervention in order to protect administrative jurisdiction has also been allowed where the court's jurisdiction was unimpeachable. ${ }^{11}$ Situations of other sorts may also call for intervention in the public interest. For example, the validity of an administrative rule may be challenged in private litigation; or an attempt may be made in a private suit to enforce a civil liability imposed for violation of a statute whose administration has been entrusted to an agency ${ }_{i}^{12}$ or a longstanding administrative interpretation of a term in a regulatory statute may become the focal point of a private suit. ${ }^{13}$

Exclusion of the agency responsible for the administration of a statute from a private proceeding in which the statute, or a rule promulgated

9a. See 81 Cong. Rec. 3254-55, 3260, 3266, 3268, 3273 (1937).

10. See notes 31 and 35, p. 72 infra.

11. United States v. American Trucking Ass'ns, 60 Sup. Ct. 1059 (U. S. 1940).

12. The Securities Act of 1933, 48 Stat. 82 (1933), 15 U. S. C. $\$ 77 \mathrm{k}$ (1934), cmpowers the purchaser of a security to sue the seller for certain violations of the Act. Analogous provisions are found in Section 18 of the Securities Exchange Act of 1934, 48 Stat. 897 (1934), 15 U. S. C. $\$ 78$ r (1934); Section 16(a) of the Public Utility Holding Company Act of 1935, 49 Star. 829 (1935), 15 U. S. C. $\$ 79 p$ (Supp. 1935); Section 323(a) of the Trust Indenture Act of 1939, 53 STAт. 1176 (1939), 15 U. S. C. A. $\$ 77 w w w$ (Supp. 1939); Section 16(b) of the Fair Labor Standards Act of 1938, 52 SrAr. 1069,29 U. S. C. $\$ 216$ (Supp. 1938).

13. In Stanford Univ. v. National Supply Co. (S. D. Cal. 1940, No. 20462) a stcelsholder sued the company for selling a security in violation of the Securities Act of 1933. The defendant asserted that no violation had occurred because under a settled construetion by the SEC of the statutory term "sale," no sale was involved. Plaintiff replied that the SEC construction was erroneous. The Commission has frequently had to determine what constitutes a sale, and the inquiry has had implications reaching beyond the relevant statutory provision. See Comment (1940) 50 Y ALE L. J. 90. 
pursuant to it, is judicially construed would seem to run counter to our entire scheme of expert administrative regulation. It is a commonplace that administrative activities have expanded in response to the need for expertise in dealing with highly technical problems. Often, too, the sheer pressure of business compels Congress to content itself with a bold ottline of policy, leaving to an administrative agency the task of interstitial legislation. Frequently, the statutes which agencies administer are closely integrated structures requiring that each section be construed in the light of seemingly unrelated sections, and also, perhaps, in the light of other acts administered by the same agency. In the case of the Securities Act of 1933, for example, the unceasing process of construction has already developed a formidable corpus of interpretations which rivals the dimensions of the gloss upon the Negotiable Instruments Law. Thus, the concept of a "security" has expanded as ingenious devices have multiplied in an attempt to escape regulation. An administrative regulation, in addition, is likely to have a background of public hearings and careful study. ${ }^{14}$ A court which is unfamiliar with this background may hit upon a construction which, in one stroke, cuts the roots of a studied administrative policy. A different result might be reached if a court were able to draw upon administrative experience to form the basis of its judgment. It is clearly in the public interest that an agency's experience should not go for naught.

Considerations of this character led to the judicially created rule of exclusive preliminary administrative jurisdiction so that courts and public might have the benefit of an expert determination as a prelude to judicial hearing. ${ }^{14 a}$ This same public interest was recognized in an intervention setting when the Supreme Court declared in the Realty case that the question whether the plan of reorganization was fair could not be answered "with any assurance . . . without resort . . . to the expert aid and advice of the" SEC. ${ }^{14 b}$ But, it may be asked, cannot an administrative agency present its views as an amicus? The support of an administrative regulation may require the introduction in evidence of underlying factual studies and investigations, and an amicus is without power to introduce evidence. ${ }^{14 c}$ Then, too, the original parties may rest content with a resolution of the question of law in the trial court which the agency may find prejudicial, and an amicus cannot appeal.

With this background of the practicalities of the intervention problem in mind, we proceed to an examination of the scope of federal intervention practice.

14. See Fuchs, Proceedings in Administrative Rule Making (1938) 52 HARv. L. REv. 259, 268.

14a. Berger, Exhaustion of Administrative Remedies (1939) 48 YALE L. J. $981,984$.

14b. 310 U. S. 434, 454 (1940).

14c. Compare Florida v. Georgia, 17 How. 478 (U. S. 1854). 


\section{The "Interest" Which Has Supported Intervention}

Traditionally, third party intervention in litigation is predicated upon an "interest in the case"15 - a concept whose origin may be traced back at least to the Roman law. ${ }^{16}$ The requirement that there be an "interest" merely reflects the orthodox prerequisite to judicial aid in any sort of proceeding: the establishment of an injury for which the law will give relief. This has been the factor which has given a party standing to institute an independent suit. No further requirements should be imposed in order to give standing to intervene. In fact, intervention has sometimes rested upon an interest which has fallen short of being a cause of action, i.e., an interest ordinarily protected against injury but which, unless intervention were allowed, would go unremedied because of circumstances peculiar to the particular case. ${ }^{17}$ An attempt to resolve the conflict between the need for protecting an applicant for intervention and the right of a litigant to conduct his own suit, by singling out certain legal rights for protection while excluding others from the protective scope of intervention, would depart from the rationale of intervention and ignore the reconciliation which has found expression in the differentiation between "permissive" and "absolute" intervention.

It scarcely needs to be added that the courts found no occasion for such analysis in the ad hoc development of intervention. In that process, whether through the accidents of litigation or otherwise, intervention by private litigants was associated with pecuniary or possessory interests. Governmental intervention, too, has at times been identified with property interests. ${ }^{18}$ But the fact that the animating principle of intervention - prevention of harm to third persons - was often applied to situations involving property interests, does not, of course, limit its scope with respect to non-pecuniary interests. ${ }^{10}$

The rules which have required a property interest as a basis for intervention have not been strictly applied to intervention by governmental bodies because the courts have recognized that a non-pecuniary interest may be as vital to a state as any possessory interest. The Realty case furnishes an example. The case was a proceeding for an arrangement under Chapter XI of the Bankruptcy Act ${ }^{20}$ whereby the debtor, a cor-

15. Equity Rule 37, adopted in 1912, reads in part: "Any one claiming an interest in the litigation may be permitted to assert his right by intervention." The rule merely purported to codify the existing practice.

16. See Moore \& Ievi, Federal Intervention (1936) 45 Yale L. J. 565, 563.

17. See notes $55,58,70,72$ infra.

18. Stanley v. Schwalby, 147 U. S. 508 (1893); Winola Lake \& Land Co. v. Gorham, 17 F. Supp. 75 (N. D. Pa. 1936); New York v. New Jersey, 256 U. S. 296 (1921).

19. It is worth noting that intervention practice is largely the product of equity. Resort to equity need not rest on a possessory interest, and equitable aid is frequently invoked precisely because damages cannot be reduced to pecuniary terms.

20. 52 STAT. 905 (1938), 11 U. S. C. $\$ 701$ et seq. (Supp. 1938). 
poration with securities outstanding in the public's hands, sought to modify certain unsecured obligations. The SEC is anthorized to participate in proceedings under Chapter X of the Act" "in the interest of adequate representation of the public interest," ${ }^{22}$ but there is no such provision for participation under Chapter XI. The Commission was permitted to intervene in order to object to the jurisdiction. It urged that Chapter $X$ prescribes the exclusive procedure for reorganization of a corporation having its securities outstanding in the hands of the public, ${ }^{23}$ and that the district court was therefore without juriscliction to entertain the petition under Chapter XI.

The stake of the public in the outcome of this case was high: preservation of the reformed reorganization procedure embodied in Chapter $\mathrm{X}$. The observed inadequacies of Section 77B, predecessor of Chapter X, had indicated the need for a larger measure of control by the courts over security holders' committees and the formulation of reorganization plans. In response to this need, Congress erected the elaborate safeguards contained in Chapter X. Chapter XI provided no comparable safeguards, being designed for compositions with trade and commercial creditors, a class who might safely be left to their own devices. ${ }^{24}$ Because "of its undoubted swiftness and its happy immunity from judicial and administrative control," Chapter XI would far too often be chosen as a vehicle of escape from the restrictions of Chapter X, and a decision which would make this possible would go "far to render abortive one of the most important corporate reforms of modern times." ${ }^{25}$ Resort to Chapter XI by a corporation which, like the debtor, should have filed under Chapter $\mathrm{X}$ would deprive investors of the safeguards erected by Congress to protect them against the inadequacies of the earlier reorganization pro-

21. 52 Stat. 883 (1938), 11 U. S. C. $\$ 501$ et seq. (Supp. 1938).

22. Sen. Rer. No. 1916, 75th Cong., 3d Sess. (1938).

23. Chapters $X$ and $X I$ "were specifically devised to afford different procedures, the one adapted to the reorganization of corporations with complicated debt structures and many stockholders, the other to composition of debts of small individual business and corporations with few stockholders . . ." Securities \& Exch. Comm. v. United States Realty \& Improvement Co., 310 U. S. 434, 447 (1940).

24. See Securities \& Exch. Comm. v. United States Realty \& Improvement Co., 310 U. S. 434, 448-451 (1940); Teton, Reorganization Revised (1939) 48 Y ALE L. J. 573; Rostow \& Cutler, Competing Systems of Reorganization, Chapters X and XI of the Bankruptcy Act (1939) 48 YALE L. J. 1334. Trade creditors are ordinarily in a position to secure information and to appear effectively in their own behalf. See Panuch, Investor Protection in Reorganization (1940) $19 \mathrm{HARv}$. Bus. REv. 21, 30. The basic assumption of Chapter $\mathrm{X}$ is that the investing public, uninformed, unorganized, widely scattered and dissociated from control or active participation in the management, "needs impartial and expert administrative assistance in the ascertainment of facts, in the detection of fratud, and in the understanding of complex financial problems." See Realty case, supra at 448 , n. 6.

25. Clark, J., dissenting in In re United States Realty \& Improvement Co., 108 F. (2d) $794,799,801,802$ (C. C. A. $2 d, 1940$ ). 
cedure - a deprivation, the Supreme Court held, against which the SEC was entitled to protest in the public interest and in the interest of its own functions.

In so holding, the Supreme Court did not, as is suggested by the categorical dissent of the minority, depart from the precedents. Intervention by the government to protect a clearly non-pecuniary interest was long ago sustained in The Exchange 2 . M'Faddon. ${ }^{20}$ A French war vessel had been libelled by American citizens to whom she had belonged and from whom she had been forcibly taken in a foreign port. The French government refused to show cause why the vessel should not be returned to the libellants. The United States District Attorney filed a "suggestion" 27 setting forth the facts and praying that the schooner be released. The district court dismissed the libel, but on appeal the circuit court reversed. The district attorney appealed to the Supreme Court, which, reversing the award of the circuit court, declared that an American citizen cannot assert title to a foreign warship in an American court. "If this opinion be correct" said Chief Justice Marshall, "there seems to be a necessity for admitting that the fact might be disclosed to the court by the suggestion of the" United States. ${ }^{27 a}$ The effect of the $E x$ change case has been summarized in Percy Summer Club a'. Astle:

"In this case neither the United States nor its citizens had any direct interest whatever, and the intervention was merely in the performance of international obligations. . . These particulars demonstrate that the rule which we are considering is of the broadest character, and is applied without formalities." 28

The right of the Federal Government to intervene was the sole question presented in Florida v. Georgia, in which the matter was exhaustively canvassed. $^{29}$ Florida had filed an original bill against Georgia in the Supreme Court to establish a boundary. The United States asked leave to intervene on the ground that a portion of the disputed land was public domain, much of which had been sold. Georgia argued that the United States had no interest, would gain no right and suffer no loss as a result of the litigation, a position which Justice Campbell adopted in his dissent. Although the decision might possibly have been rested on the narrow proprietary or pecuniary interest of the United States, Chief Justice

26. 7 Cranch 116 (U. S. 1812).

27. In Stanley v. Schwalby, 147 U. S. 508, 513 (1893) the Supreme Court assimilated this practice to intervention, saying it is proper for the government "to intervene by way of suggestion."

27a. 7 Cranch 116, 146 (U. S. 1812).

28. 110 Fed. 486,489 (C. C. D. N. H. 1901).

29. 17 How. 478 (U. S. 1854). Taney, C. J., wrote an extensive majority opinion. Campbell, J., wrote a lengthy dissent, as did Curtis, J., MicLean, J., concurring. Justice Daniel dissented without opinion. The decision sustaining intervention is the more remarkable in view of the formidable constitutional objections that were raised. 
Taney, speaking for the majority of the Court, chose to take a broader view, saying:

"The case, then, is this: Here is a suit between two States, in relation to the true boundary line which divides them. But there are twenty-nine other states, who are also interested in the adjustment of this boundary, whose interests are represented by the United States. Justice certainly requires that they should be heard before their rights are concluded by the judgment of the court." ${ }^{30}$

That a governmental agency may intervene to protest against an interference with its administrative functions is illustrated by Pennsylvania v. Williams. ${ }^{31}$ In that case, a New York shareholder in Mortgage and Loan Association, a Pennsylvania corporation, instituted a receivership proceeding in a federal court, naming the association as defendant. The state of Pennsylvania, alleging that the state laws afforded a comprehensive scheme of liquidation for such a building and loan association, filed a petition ${ }^{32}$ for leave to intervene and for an order directing the receivers to surrender the assets of the association to the State Secretary of Banking for liquidation. The Supreme Court reversed the denial of the petition by the district and appellate courts, held that the district court should have discharged the receivers, and ordered the district court

30. 17 How. 478, 494 (U. S. 1854) ; cf. New York v. New Jersey, 256 U. S. 296, 302, (1921). See Pollen v. Ford Instrum. Co., 26 F. Supp. 583 (E. D. N. Y. 1939) where the Government was permitted to intervene in a patent infringement suit in order to protest against disclosure of military secrets that would be detrimental to the public interest.

31. 294 U. S. 176 (1935). The Supreme Court again recognized in Coleman v. Miller, 307 U. S. 433, 442, 466 (1939) :

"the legitimate interest of public officials and administrative commissions, federal and state, to resist the endeavor to prevent the enforcement of statutes in relation to which they have official duties."

State courts have frequently held that an interest in the preservation of governmental functions against judicial impairment through an improper exercise of jurisdiction confers standing to invoke a writ of prohibition. In State v. Superior Court for Walla Walla County, 159 Wash. 335, 293 Pac. 986 (1930), the prosecuting attorney for King County sought a writ of prohibition to prevent the superior court of Walla Walla County from issuing a habeas corpus to bring one Garrison from an institution for the criminal insane, on the ground that the superior court for King County had exclusive jurisdiction to pass on the discharge. The relevant statute required that the prosecuting attorney be served with notice of the petition for discharge, and resist the same. His statutory duties were held to constitute a "beneficial interest" for the purposes of maintaining the prohibition proceeding. See also State v. Alexander, 87 Utah 376, 49 P. (2d) 408 (1935); State v. Superior Court of Marion County, 202 Ind. 589, 177 N. E. 322 (1931) ; cf. In the Matter of N. L. R. B., 304 U. S. 486, 496 (1938).

32. But the intervention was in fact if not in form by the statutory liquidator: "the state officer, charged by the statutes of the state with the duty of supervising its own building and loan associations and of liquidating them by an adequate procedure when insolvent, asks to proceed with the liquidation." 294 U. S. 176, 184 (1935). 
to direct the surrender of the property held by the receivers to the Secretary of Banking. By necessary implication, the granting of this relief recognized that the state had an interest which gave it standing to intervene.

The minority of the Supreme Court in the Realty case found Pemsylvania $v$. Willians "inapposite," apparently on the ground that the state "claimed a right to full possession and control of the assets of the insolvents, not merely a right to advise or protect the public interest." 33 But "possession" of the assets was merely an incident of the protection which Pennsylvania sought to furnish public investors. To make effective protection of the public interest depend upon the fortuitous presence of that incident ${ }^{34}$ is both unrealistic and contrary to the principle established in The Exchange and Florida cases. It is unrealistic because:

"Neither the liquidator nor the state has any personal, financial or pecuniary interest in the property in the custody of the federal court. Their only interest, like that of the Commission, is a public one, to maintain the state authority and to secure a liquidation in conformity to state policy."35

Cases involving independent suits brought by a state or the United States illustrate even more clearly that the state's interest in the welfare of its citizens, divorced from any "proprietary" or "possessory" considerations, may confer standing in court upon a governmental body. In Georgia v. Temessee Copper Co., the state of Georgia filed a bill in equity to enjoin the defendant copper companies from discharging noxious gas from their works in Tennessee over Georgia territory, alleging that the discharge resulted in a wholesale destruction of forests, orchards and crops. The Supreme Court, speaking by Mr. Justice Holmes, declared that the state, in its capacity of quasi-sovereign,

"has the last word as to whether its mountains shall be stripped of their forests and its inhabitants shall breathe pure air. . . . The alleged damage to the State as a private owner is merely a make-

33. The language is that of the majority opinion in the Circuit Court of Appeals. 103 F. (2d) 794,798 (C. C. A. 2d, 1940).

34. No emphasis upon "possession" is found in Penusylzania a. Mrilliams. On the contrary, the case sought to discourage "an unnecessary interference by injunction with the lawful action of state officers" engaged "in carrying out their [the state's] domestic policy." 294 U. S. 176, 185 (1935).

35. Securities \& Exch. Comm. v. United States Realty \& Imp. Co., 310 U. S. 434, 460 (1940). In State v. Superior Court of Mfarion County, 202 Ind. 589, 177 N. E. 322 (1931) a state banking commissioner was permitted to intervene in an aetion for a writ of prohibition to prevent a state court from exercising jurisdiction to anpoint a receiver for a state bank at the instance of a creditor. The commissioner neither had nor claimed possession of the assets; his "interest" consisted in the fact that he alone was entitled to ask for a receiver. 
weight, and we may lay on one side the dispute as to whether the destruction of forests has led to the gullying of its roads." g6

That principle had earlier found expression in In re Debs, a suit by the United States to enjoin the defendant from obstructing the mails and interstate transportation of persons and property. The court declared that the Federal Government:

"with powers and duties to be exercised and discharged for the general welfare, has a right to apply to its own courts for any proper assistance in the exercise of the one and the discharge of the other, and it is no sufficient answer . . . that it has no pecuniary interest in the matter." 37

The same doctrine has been more recently declared in Hopkins $v$. Cleary, a case in which the Wisconsin Banking Commission sued a domestic savings and loan association to annul proceedings in which the latter had attempted to convert itself into a federal association. In answer to a challenge of the Commission's standing, the Court stated:

"It is of no moment in such conditions that the interest of the state in repelling the encroachment is other than pecuniary . . . at least there is 'a matter of grave public concern in which the state as the representative of the public has an interest. apart from that of the individuals affected." "38

It would be anomalous to hold that a public interest not measurable in pecuniary terms may serve as the basis of an independent suit and yet be insufficient to support intervention for the protection of the very same interests. Indeed, recognition of a non-pecuniary interest as the basis of intervention in the Exchange and Florida cases preceded the holding in the Debs case that the Government had standing to enjoin an interference with its functions. At any rate, any doubts raised by the circuit court of appeals in the Realty case as to the sufficiency of a non-pecuniary governmental interest as a basis for intervention were put to rest, at least so far as permissive intervention is concerned, by the decision of the

36. 206 U. S. 230, 237 (1907); cf. New York v. New Jersey, 256 U. S. 296, 302, (1921). The representation of the public interest may of course be delegated by the state to an administrative body. See Interstate Commerce Comm. v. Oregon-Wash. R. R., 288 U. S. 14, 25 (1933) (in suit brought to enjoin an order of the Interstate Commerce Commission, state utility commissions, which had intervened in the suit, were held to be "aggrieved parties" and therefore had a statutory right of appeal "because they officially represent the interest of their states in obtaining adequate transportation service.")

37. 158 U. S. 564,584 (1895).

38. 296 U. S. 315, 339-340 (1935). The public interest of a state in the maintenance of transportation facilities has been held to give it standing to ask for a writ of prohibition forbidding a judge who had entered a foreclosure decree to confirm the sale of railroad property as junk. State v. Bullock, 78 Fla. 321, 82 So. 866 (1919). 
Supreme Court in that case. ${ }^{39}$ The Court, however, found it unnecessary to decide whether the SEC had an absolute right to intervene. ${ }^{40}$ Succeeding sections of this Article will attempt to show that a well-defined public interest, together with satisfaction of the other requirements of Rule 24, are sufficient to support intervention in both the "permissive" and the "absolute" situations.

\section{Permissive Intervention}

Rule 24, which purposes to amplify and restate the existing practice,"11 declares with respect to permissive intervention:

"(b) ... any one may be permitted to intervene in an action:

(1) when a statute of the United States confers a conditional right to intervene; or (2) when an applicant's claim or defense and the main action have a question of law or fact in common."

The problem of this section is the determination of whether a public agency's attempt to represent the public interest and protect its own functions may constitute a "claim or defense" within the meaning of the Rule. ${ }^{42}$

As used in the Rule, the terms "claim or defense" present troublesome questions of construction - problems which are not altogether resolved by the Supreme Court's opinion in the Realty case. Although the Court

39. "The Commission is, as we have seen, charged with the performance of important public duties in every case brought under Chapter $\mathrm{X}$, which will be thwarted, to the public injury, if a debtor may secure adjustment of his debts in a Chapter XI proceeding when, upon the applicable principles which we have discussed, he should be required to proceed, if at all, under Chapter X. . . . The Commission . . . [intervened] . . . to object to an improper exercise of the court's jurisdiction which, if permitted to continus, contrary to the court's own equitable duty in the premises, would defeat the public interests which the Commission was designated to represent . . ."

"If, as we have said, it was the duty of the court to dismiss the Chapter XI proceeding because its maintenance there would defeat the public interest in having any scheme of reorganization of respondent subjected to the scrutiny of the Commission, we think it plain that the Commission has a sufficient interest in the maintenance of its statutory authority and the performance of its public duties to entitle it through interiention to prevent reorganizations, which should rightly be subjected to its serutiny, from proceeding without it." 310 U. S. $434,458-460$ (1940).

40. 310 U. S. $434,458(1940)$.

41. The Advisory Committee states in a note to Rule 24: "This rule amplifies and restates the present federal practice at law and in equity." Notrs to FED. RULES Crv. Proc. (1938) 25. See note 56 infra.

42. In discussing the relation between governmental intervention and Rule 24 , it is advisable to keep in mind that even if intervention in the public interest is not strietly within the scope of the Rule, equity precedents may be drawn upon to base intervention when harm will thereby be prevented. Compare Mir. Justice Stone's statement in the Realty case as to the duty of the district court to relinquish its jurisdiction. $310 \mathrm{U}$. S. $434,455,457$ (1940). 
spelled out the interest of the Commission at length, it dealt only summarily with the question of "claim or defense," stating simply that:

"The 'claim or defense' of the Commission founded upon this interest has a question of law in common with the main proceeding in the course of which any party or a creditor could challenge the propriety of the Court's proceeding under Chapter XI." 43

It might, however, have been argued that the term "defense" means a defense to a particular claim already asserted in the action." On the other hand, an objection to a lack of jurisdiction is specifically named a "defense" in Rule 12(b). This is not to say that a complete stranger to a suit may interpose an objection to the jurisdiction. Yet persons without standing to file pleadings or otherwise contest the allegations of a petition have been permitted to intervene in bankruptcy proceedings for the purpose of objecting that the proceeding ought not to be allowed to go forward. ${ }^{45}$ A construction of the term "defense" in Rule 24(b)(2) which also permits a public agency to protest against an improper exercise of jurisdiction that is likely to injure the public interest and its own functions seems eminently reasonable and just.

Had the Court merely declared that the SEC's objection to jurisdiction was a "defense," it might be possible to base an argument confining the decision to objections to the jurisdiction and other "defenses" enumerated in Rule $12(\mathrm{~b})^{46}$ on the Court's invocation of the broad bankruptcy practice which permits "creditors or others not entitled to file pleadings or otherwise contest the allegations of a petition" to object to continuation of the proceedings. ${ }^{47}$ But the Supreme Court described the SEC's interest as a "claim or defense." In view of the fact that the SEC had relied upon the existence of a "defense" alone, this inclusion of "claim" may indicate an intention not to confine intervention to cases involving objections to jurisdiction and similar "defenses."

43. 310 U. S. 434,460 (1940).

44. FED. Rules Civ. Proc. 8(b) : "A party shall state in short and plain terms his defenses to each claim asserted [presumably against him] and shall admit or deny the averments upon which the adverse party relies." And see RuLes 8(c), 8(e) (2) and 12(b).

3 OHlinger, Federal Practice (1939) 421, speaking of a case in which an application to intervene was addressed to the discretion of the district court, states: "There is some doubt whether, under the present rule, the court would have a discretion to permit intervention in such a case since the use of the words applicants' 'claim or defensc' may be taken to imply that the intervenor's interests must be sufficient to support an independent proceeding by or against such an intervenor."

45. See cases cited 310 U. S. 434,458 , n. 9 (1940).

46. Fed. Rules Civ. Proc. 12(b) provides that the following "deienses" may be made by motion: ". . . (1) lack of jurisdiction over the subject matter, (2) lack of jurisdiction over the person, (3) improper venue, (4) insufficiency of process, (5) insufficiency of service of process, (6) failure to state a claim upon which relief can be granted."

47. See 310 U. S. $434,457,458,460$ (1940). 
A broader view of the term "defense" than was called for by the Realty case is illustrated by a companion Supreme Court decision, United States v. American Trucking Associations. ${ }^{48}$ This was an action by the Trucking Associations to compel the Interstate Commerce Commission to consider their petition for establishment of reasonable requirements with respect to the qualifications and hours of service of certain employees of motor carriers. The ICC disclaimed jurisdiction. The Wages and Hours Division of the Department of Labor was allowed to intervene in support of the ICC's position, and in its answer denied the power of the ICC to regulate the employees in question because these employers were subject to the provisions of the Fair Labor Standards Act and therefore subject to regulation by the intervener. ${ }^{\text {to }}$ This was of course a "defense." Conceivably, however, the same interest might support a "claim" in another situation. Had the Trucking Associations enjoined the ICC from enforcing an order directing the Associations to perform certain acts, the Wages and Hours Division might have intervened as party plaintiff, claiming affirmative relief on the ground that the ICC's order constituted an impairment of the intervener's functions.

An analysis of intervention in terms of plaintiff and defendant, in accordance with the traditional code view, ${ }^{50}$ possibly would seem to have no place in ascertaining the status of interveners such as the SEC in reorganization and bankruptcy proceedings. These proceedings are not

48. 60 Sup. Ct. 1059 (U. S. 1940).

49. Record, pp. 30-31, United States v. American Trucking Ass'ns, 60 Sup. Ct. 1059 (U. S. 1940). Although the propriety of the intervention was not questioned, the Supreme Court in adverting to the intervention cited the companion Really case (n. 14), where the intervention issue was squarely presented.

The suggestion in 3 Fed. Rules Serv. Cosrar. 24 b 2-2 that the Really case may be rested upon the direction in General Order in Bankruptcy 37 to apply the Rules of Civil Procedure "as nearly as may be" and therefore that bankruptey cuurts alone may permit intervention for purposes of objecting to continuance of the proceceling is in the writer's opinion untenable. A narrow construction of "defense," limiting it to objections to continuation of bankrtiptcy proceedings, had been advanced by the government in the Realty case. Brief for the United States, pp. 49-50. The Court's failure to adopt the argument, its use of "claim or defense," and reliance upon Pemsylzania ". Williams, an equity case, and finally the citation of the Realty case in the Trucling case, all point to a less restricted view of governmental intervention.

50. Traditionally an intervener either joined the plaintiff in claiming what was sought by the complaint, or the defendant in resisting plaintiff's claim, or he demanded something adversely to both. Rocea v. Thompson, 223 U. S. 317, 331 (1912); Clark, Code PlendING (1928) 287-288; Moore \& Levi, sttpra note 4, at 565 . Viewed in the frameworl; of this practice, Indian Refining Co. v. Dallman, 31 F. Supp. 455 (S. D. Ill. 1940) discloses faulty analysis. That case was an action against the Refining Co. to recover tases paid under protest of a ruling that one Kolb and his employees were employees of the Refining Co. for tax purposes. Kolb sought to intervene on the ground that he was by contract ultimately liable for the taxes. The court permitted intervention under Rule 24(b) (2) saying: "Kolb's claims have questions of law and fact in common with those presented in the plaintiff's complaint." Since Kolb joined the Refining Co. in resisting the plaintiff's claim, he was, strictly speaking, interposing a defense. 
law suits in the sense that a suit is a proceeding designed to settle simple issues between individual litigants, but proceedings in rem in which there may be many parties, all with thoroughly divergent interests. Even if a reorganization situation is viewed from the standpoint of conventional code practice, such interveners as the SEC may have a "claim" in that they demand something adversely to the original parties, i.e., that the proceedings be terminated. ${ }^{51}$ In this view, the Realty situation resembles the cases in which a governmental body has sought affirmative relief against an impairment of its functions. ${ }^{52}$

It might be argued that the term "claim" in Rule 24 is a word of art, employed in place of "cause of action" in order to escape the limitations which had encrusted the older term. This contention finds support in the freedom with which "claim" is used throughout the Rules to express the concept generally spoken of as a "cause of action." 53 The fact that the technical word "claim" is used in the permissive intervention section of Rule 24, rather than the broad term "interest" which is used in the same Rule to base intervention of right, seems to suggest that a "claim" differs from an "interest" - perhaps that it requires interest sufficient to constitute a "cause of action." "64 But to restrict "claim" to a "cause of action" would result in cutting down the existing scope of permissive intervention, ${ }^{55}$ a result which is at odds with the expressed intention that

51. See note 50 supra. The writer assumes that the creditors claiming adversely to the debtor may, like the debtor, be interested in the continuance of the proceeding and that the SEC alone will object to the jurisdiction.

52. See notes 31 and 35 stupra.

53. 'Nowhere in the Rules is the term 'cause of action' used. This can only mean that the draftsmen, by the use of the phrases 'claim' or 'claim for relief,' hoped that such different expressions in lieu of 'cause of action' would give the courts freedom to escape from the morass of decisions concerning a cause of action; and would adopt a pragmatic treatment of what we may for convenience still refer to as a cause of action." 1 MookE, Federal Practice (1938) 145; Pike, Objections to Pleadings Under the New Federal Rules of Civil Procedure (1937) 47 YALE L. J. 50, 68-69.

Rule 8 provides that "a pleading which sets forth a claim for relief . . . shall contain . . (2) a short and plain statement of the claim showing that the pleader is entitled to relief." Among the defenses listed in Rule 12(b) is "(6) failure to state a claim upon which relief can be granted." And see Rules $13(\mathrm{a}), 13(\mathrm{~b}), 13(\mathrm{~g}), 15(\mathrm{c}), 18,22$, 26(b). Compare Pampanga Sugar Mills v. Trinidad, 279 U. S. 211, 218 (1929); cf. note 44 supra.

54. The change from "interest" to "claim" might find explanation in the fact that permissive intervention had largely been a matter of trial convenience, so that if an applicant for relief had an independent cause of action he might at the convenience of the court be remitted to his independent suit ("claim"). Long v. Stites, 63 F. (2d) 855 (C. C. A. 6th, 1933) ; United States v. Phillips, 107 Fed. 824 (C. C. A. 8th, 1901); 2 MoonE's Federal Practice (1938) 2332. But where the petitioner's interest did not rise to the dignity of a cause of action (see note 58 infra) and he could obtain relief only by intervention in the pending cause, his right to intervene was absolute. See cases cited infra notes 69,71 .

55. It is difficult to conceive the claim interposed by the Government in the Exchange case, for example, in terms of a cause of action. 
Rule 24 amplify or restate existing federal intervention practice. ${ }^{.5}$ Moreover, it does not necessarily follow that because "claim" was substituted for "cause of action" for purposes of drawing a complaint, it must mean exactly the same thing in a context of intervention. Indeed, it would be anomalous to introduce the restriction that the interest required for intervention must be one which will support a "cause of action," through the medium of a word that was employed in order to escape from the limitations that cluster about the very phrase. It is plain, further, that the framers of the Rules did not intend that "claim or defense" be narrowly construed. ${ }^{57}$ It can also be argued the Supreme Court adopted this Rule and is presumably free to declare its own "legislative" intention - that, for purposes of intervention by the Government, the word "claim," in consonance with prior intervention practice, was intended to embrace interests which because of circumstances peculiar to the case do not amount to a cause of action. ${ }^{58}$ In any event, the Court's liberality

56. See note 41 supra. The only departure made from previous federal practice was the omission of the requirement that intervention be in subordination to the original suit. Dean (now Circuit Judge) Clark, who served as Reporter to the Advisory Committee which directed the preparation of the Rules, stated:

"Rule 24 deals with the matter of intervention. There, too, we have attempted to make some statements which either do not change the law, or, if they do, only change it slightly. The rule is intended to be, in other words, a clarification of a rather confusing subject, rather than otherwise.

"The old Equity Rule was a fairly broad rule of intervention, but with the provision that the intervention must always be in subordination to the original suit, an expression which has never been clear, and the exact meaning of which can't well be ascertained.

"If one were to take the statement at its face value, the intervener could do nothing about the original suit, but allow it to go to judgment, for the real reason of his coming in is because he wanted to fight the original suit. So we have left out that form of expression but have attempted to clarify the situation rather generally by a little more detail and a little more classification." Proceronics on Federal Rules, Cleveland (Am. Bar. Ass'n, 1938), 265-6.

57. After stating the requirements for intervention of right under Rule 24, Dean Clark stated that permissive intervention may be allowed in "any other case where a question of law or fact in common with the main suit is presented." Procennr:ics o: Ferezul. Rules, Washingron (Am. Bar Ass'n, 1939) 67. (Italics supplied).

58. In Dodd v. Reese, 24 N. E. (2d) 995 (Ind. 1940), infra note 72, an attempt was made to set aside certain adoption proceedings because they had allegedly been procured through the fraud of Dodd, an attorney. Dodd sought to intervene on the ground that a decision for the plaintiff would be an adjudication that Dodd was guilty of fratul, and that he would be remediless since statements made in a pleading are privileged. Intervention was denied. On appeal, the state supreme court directed that Dodd be allowed to intervene. See note $\mathbf{5 5}$ supra and note $\mathbf{7 0}$ infra.

Although a litigant may in this situation claim that he may intervene as of right because of the absence of another remedy, the ruling of a trial court fermilling him to intervene should obviously not be reversed because the court accorded him the lesser privi- 
in interpreting "claim or defense" in the Realty case may indicate that Rule 24 will be construed with an eye to whether there is a practical need for intervention rather than to terminological niceties.

\section{INTERVENTION OF RIGHT}

It has been noted that the Supreme Court did not decide whether the SEC could intervene as of right in the Realty case, but left unchallenged the decision of the Second Circuit Court of Appeals that the SEC had no absolute right, and its statement that a "governmental agency had no general right of intervention "in the public interest." "60 As athority for this statement the court below cited Professor Moore. Moore in turn states:

"Prior to the Act of August 24, 1937, infra, the United States had no general right of intervention. The inability of the federal or state governments to intervene as of right . . . finds a counterpart in other legal systems, as, for example, Germany." "0

No authority is cited for the proposition that federal and state governments are unable to intervene as of right, nor can the reference to German practice be rested upon the authority cited. ${ }^{11}$ France, on the other hand, has long known very broad powers of intervention in the public interest.02

In support of the position that the Government has no general right to intervene, it may, of course, be urged that the 1937 grant of authority

lege. To bring the trial court's action within the technical language of Rule 24(b) (2), which governs permissive intervention, it is necessary to construe "claim" broadly. See also note 73 infra.

59. 108 F. (2d) 794, 798, 801.

60. 2 Moore's Federal Practice (1938) 2327.

61. The cited article merely indicates that, unlike the French procureur, the German state's attorney (Staatsanwalt) who initiates criminal proceedings has no standing to intervene in civil suits. "As in France, criminal proceedings are ordinarily initiated by the state's attorney (Staatsanwalt). His office . . . is modeled, in part on the pattern of the French parquet [public ministry]. Unlike the French procurettr . . . the German Staatsanzvalt has [with certain exceptions] no standing, however, in civil cases . . . ." Deak and Rheinstein, The Machinery of Law Administration in France and Germany (1936) 84 U. of PA. L. Rev. 846, 868. The procurettr is an organ of the French public ministry, dating back to the 14 th century, which is headed by the minister of justice and has very extensive powers of intervention in the public interest. For example, the procureur "must be heard in every case of every kind before the Court of Cassation, prcsumably on the theory that every case reaching the highest court of France affects the public interest." Id. at 858. "The role assigned to these officials is to represent the state and protect the public interest whenever and however it may be involved .... In the exercise of his functions of judicial administration the appropriate procureur . . . may intervene in suits of private parties." Id. at 857. While the office of Staatsanzerlt is to some extent modeled on that of the procureur, nothing contained in the material cited warrants the inference that the power of intervention which is withheld from the Staatsamwall is completely withheld from the German government.

62. See note 61 supra. 
to intervene in specific situations manifests an intention to limit the power to those instances and withhold it in circumstances not enumerated. Intervention is, however, a judicial rather than a legislative creation, and any statutory limitation on the right must be expressed in clear and unambiguous terms. The Supreme Court declined in the Realty case to construe the explicit statutory authority of the SEC to appear in Chapter $\mathrm{X}$ bankruptcy proceedings as a limitation upon its right to intervene in a Chapter XI proceeding. ${ }^{63} \mathrm{~A}$ similar position is even more justified with respect to the Act of 1937. Although the cases in which the Supreme Court had permitted federal and state agencies to intervene were apparently not called to the attention of Congress, ${ }^{\text {of }}$ recognition of the Government's right to intervene wherever it has an interest is visible in both the Senate and House debates. Senator Austin, who explained a part of the bill on behalf of the draftsmen, said that "the government may intervene if it . . . has a duty to perform on behalf of all the citizens of the United States who would be affected by the proceedings. This is recognized . . ." by Equity Rule $37 .{ }^{05}$ In the House, Mr. Gwynne attacked the bill insofar as it purported to permit intervention in the absence of an "interest" on the ground that; if the other parties were satisfied with the judgment in the trial court, the Government would on appeal be seeking a declaratory judgment in a moot controversy. But he, too, stated that where the Government had an interest, it could appear without statutory authorization. ${ }^{\mathrm{CB}}$ In short, there is nothing in the Act of 1937, or in its legislative history, which suggests that Congress intended to repudiate the cases to which we now turn.

In Pennsylvania v. Williams ${ }^{67}$ the district court denied the state's petition asking both leave to intervene and affirmative relief. The state

63. The argument had been pressed on the Court. Brief for Respondent, p. 36, Securities \& Exch. Comm. v. United States Realty \& Imp. Co., 310 U. S. 434 (1940).

64. Senator Austin directed attention to In re Debs, 158 U. S. 564 (1895) which recognizes that there is a non-pecuniary governmental interest for purposes of maintaining an injunction suit (81 CoNG. REC. 8510-8511 (1937)), but the debates do not mention the cases cited supra note 5 and infra note 67.

65. 81 Cong. Rec 8509 (1937). See also id. at 3262-3263.

66. Id. at 3262-3264. See also SEN. Rep. No. 963, 75th Cong., 1st Sess. (1937). ... Although the debaters use the word "permit," that word was employed in the Act which conferred an absolute right, and the context shows that the debaters had reference to intervention of right.

Another objection in the House to enactment of the bill was that Governmental participation would injure the poor litigant by protracting litigation. See 81 Co:sc. Rrc. $3257,3258,3265$ (1937). Here, it may be said that the Government is, like other litigants, entitled to defend its interests against injury. And the larger interest of the pullic in questions involving the public interest may outweigh the hypothetical injury to the individual litigant. Id. at $3265,3273$.

67. 294 U. S. 176 (1935); see pp. 72, 73 supra. Prior to the Act of 1937 the Collector of Internal Revenue was permitted to intervene in private litigation which challenged the validity of the Social Security Act, Norman v. Consol. Edison Co., 89 F. 
took the case to the Third Circuit Court of Appeals, which affirmed, and thence to the Supreme Court. The Supreme Court's mandatory direction to grant the relief sought necessarily implied that the petitioner must be permitted to intervene. Even if that implication were clothed in terms of the district court's abuse of discretion, it would yet in practical effect confer an absolute right to intervene. ${ }^{68}$

The necessary implication of Pennsylvania v. Williams may be supplemented by Florida $v$. Georgia, which affords an early illustration of the principle that, in the absence of any other remedy, the right to intervene is absolute. ${ }^{69}$ That case was an original bill in the Supreme Court involving a boundary dispute between the two states in which the United States sought to intervene. It cannot be unduly emphasized that the objection to intervention by the United States was that by the very terms of the Constitution it could not be a party to a suit between two states in the Supreme Court. Nevertheless, the Court found it necessary to permit the Government to intervene and to accord it the rights of a party - introduction of evidence and cross-examination - saying, by Chief Justice Taney:

(2d) 619 (C. C. A. 2d, 1937) ; Davis v. Boston \& M. R. R., 89 F. (2d) 368 (C. C. A. 1st, 1937), and to appeal from an adverse decision, Helvering v. Davis, 301 U. S. 619 (1937). The interest of the Collector was of course not a personal, pecuniary interest but an interest in preserving administrative functions, and in the light of the Really case it is no longer possible to distinguish these cases on the ground that they involve a "pecuniary" interest. As a practical matter the government's interest in preserving regulatory functions is often little less important than the tax collecting function.

68. This by Moore's own reasoning: "In referring to that large class of cases in which permission to intervene must be granted and where denial thercof is always an abuse of discretion, it seems artificial to talk in terms of discretion, the right being, rather, absolute." 2 Moore's Federal Practice (1938) 2332. And see 3 Onlinger's Fed- . eral Practice (1939) 387; cf. United States v. Houde Engineering Corp., 9 F. Supp. 836, 839 (W. D. N. Y. 1935).

Moore states that a "holding by a court that the petitioner has a right to appeal such an order [denying intervention] is always a holding that the petitioner's right of intervention is absolute." MOORE, loc. cit. supra. Applying this criterion, the allowance of an appeal in the Willians case after denial of intervention would mark it as a case of absolute intervention. The present validity of this test may, however, be doubted, for a denial of permissive intervention may henceforth be appealable. Whether the applicant has a "claim or defense" or whether the claim or defense have questions of law or fact in common with the main action are questions of law which it seems should be revicwable.

69. 17 How. 478 (U. S. 1854). See United States Trust Co. v. Chicago Term. R. R., 188 Fed. 292, 296 (C. C. A. 7th, 1911). Washington v. United States, 87 F. (2d) 421, 434 (C. C. A. 9th, 1936) ; Board of Comm'rs v. Bernardin, 74 F. (2d) 809, 816 (C. C. A. 10th, 1934); Guaranty Trust Co. v. Minneapolis \& St. L. R. R., 52 F. (2d) 418, 422 (C. C. A. 8th, 1931). And see cases cited note 54 supra, note 71 infra. If existing remedies "are clearly less practicable and efficacious to the ends of justice than intervention in the present suit" the order denying intervention is appealable, i.c., the right to intervene is absolute. United States v. Radice, 40 F. (2d) 445, 446 (C. C. A. 2d, 1930) (Italics supplied). 
". . . the United States have a deep interest in the decision of this controversy. And if this case is decided adversely to their rights, they are without remedy, and there is no form of proceeding in which they could have that decision revised in this court or elsewhere. Justice, therefore, requires that they should be heard before their rights are concluded."70

The distinction between the absolute and permissive right to intervene had not yet been formulated, but the judicial insistence that under the extraordinary circumstances of the case the Government must be heard indicates that the right should be regarded as absolute.

Application of the governing principle of absolute intervention to private litigants has developed certain categories, e.g., one who claimed an interest in property in the court's custody has been said to have an

70. 17 How. 478, 493 (U. S. 1854) (Italics supplied). The opinion in the Really case leads one to believe that the Supreme Court would scarcely have sustained a denial of intervention in that case. The Court found that the SEC is "charged with the periormance of important public duties . . . which will be thwarted, to the public injury" by an improper continuation of the Chapter XI proceeding. The Commission, continued the Court, "has a sufficient interest in the maintenance of its statutory authority and the performance of its public duties to entitle it through intervention to prevent reorganizations which should rightly be subjected to its scrutiny from proceeding without it." 310 U. S. 434, 458-460 (1940). And it indicated that the question of the "fairness" of the plan could not be answered without resort to the "expert advice" of the Commission. Id. at 458. It therefore seems unlikely that a district court will in these circumstanees be permitted to exclude the SEC.

In the writer's opinion, the right of the SEC to intervene in the Reolly case was absolute because the Commission had no other means for protecting the public interest. Ordinarily a protest against an impairment of administrative functions may be made in an independent suit. See notes 30 and 35 supra. But a writ of prohibition would have been unavailable in a circuit court of appeals because it deprived the court of an appeal. Hammond Lumber Co. v. United States Dist. Crt., 240 Fed. 924, 928 (C. C. A. 9th, 1917); In re Heilbroner, $69 \mathrm{~F}$. (2d) 643,644 (C. C. A. 2d, 1934). The writ may likewise have been unavailable in the Supreme Court for a similar reason. Cf. Mfuir v. Chatficld, 255 Fed. 24, 26 (C. C. A. 2d, 1918) ; cf. 36 Stat. 1156 (1911), 28 U. S. C. $\$ 342$ (1934); Ex parte Easton, 95 U. S. 68, 72 (1877) ; Ex parte Baleelite Corp., 279 U. S. 438, $44 S$ (1929). In re N. L. R. B., 304 U. S. 486 (1938), is not to the contrary because, had the writ been denied, "no adequate remedy would be open to the Board by way of certiorari from the Court's ultimate review of an order which the Board was authorized and desired to set aside." The writ in that case therefore issued in aid of the Supreme Court's appellate jurisdiction.

In the light of the Realty decision, we now know that mandamus likewise would not be a remedy available to the SEC. The Supreme Court held that the district court had discretion to determine whether the relief afforded by Chapter XI was adequate, and that it should have dismissed the petition in the exercise of a "sound discretion." 310 U. S. 434, 456 (1940). Mandamus will not lie to control the exercise of discretion. See Hudson v. Parker, 156 U. S. 277, 288 (1895); Interstate Commerce Comm. v. Waste Merchants Ass'n, 260 U. S. 32, 34 (1922) ; Miguel v. MicCarl, 291 U. S. 442, 451 (1934); Allison \& Co. v. Interstate Commerce Comm., 107 F. (2d) 180, 182 (App. D. C. 1939). Intervention therefore seems to be the only remedy available to the SEC. 
absolute right to intervene. ${ }^{71}$ It is not here necessary to inquire how far these categories exhaust the scope of the principle with respect to private litigants, ${ }^{72}$ for, as regards early practice in Government intervention, Florida $v$. Georgia demonstrates that the bare fact that the public interest might be prejudiced and left without remedy required that the Government be allowed to intervene.

The touchstone of the right to intervene at common law - the presence or absence ${ }^{73}$ of another suitable remedy - was not embodied in the ambiguous terms of former Equity Rule 37,74 adopted in 1912, although the courts continued to employ this criterion. ${ }^{75}$ Nor does Rule 24 in terms employ the common law test. Instead, the Rule confers the absolute right to intervene:

"(a) ... (1) when a statute of the United States confers an unconditional right to intervene; or (2) when the representation of the applicant's interest by existing parties is or may be inadequate and the applicant is or may be bound by a judgment in the action; or (3) when the applicant is so situated as to be adversely affected by a distribution or other disposition of property in the custody of the court or an officer thereof."

This reformulation of intervention practice makes it necessary to inquire whether the absolute right apparently conferred by the Williams and Florida cases may be fitted within the requirements of one of these subdivisions. $^{75 a}$ The Act of 1937, permitting the Government to intervene wherever the constitutionality of a federal statute is drawn into question, seems to be the type of statute contemplated in 24(a) (1). Government

71. Credits Commutation Co. v. United States, 177 U. S. 311, 315 (1900); Minot v. Mastin, 95 Fed. 734, 739 (C. C. A. 8th, 1899).

72. An example of the continuing flexibility of intervention practice is furnished by Dodd v. Reese, 24 N. E. (2d) 995 (Ind. 1940), supra note 58. Although Dodd had no interest in property held by the court and his interest did not fit into the ustual categories of absolute intervention, the court was impelled to order that he be allowed to intervene because he was without other remedy. See also note 73 infra.

73. See notes 54, 69, 71 infra.

Glass v. Woodman, 223 Fed. 621 (C. C. A. 8th, 1915) (cited for the proposition that the absence of another remedy is not the sole test of an absolute right to intervene in Demulso Corp. v. Tretolite Co., 74 F. (2d) 805,808 (C. C. A. 10th, 1934)) involved an attempt to inject a completely extraneous issue into the proceeding. Canadian bondholders sued to foreclose bonds of a Missouri railroad and deposited their bonds with the Master. Applicant sought intervention to sue for an unrelated breach of contract, because he could not get service or attach other property in the United States. The court properly excluded him, saying that his claim "had no relation to any phase of the cause of action or the subject matter in the court below. It is outside of and forcign to the litigation." Id. at 622 .

74. Equity Rule 37 reads in part: "Anyone claiming an interest in the litigation may be permitted to assert his right by intervention ..."

75. See cases cited supra note 69.

75a. But cf. note 42 supra. 
bodies, seemingly, are little affected by the provisions of 24(a)(3). Most questions involving governmental intervention of right in the public interest will arise under 24(a)(2).

The prerequisites to intervention of right under Rule $24(\mathrm{a})(2)$ are three: (1) an interest, which (2) may be inadequately represented, and (3) may be bound by the judgment. The Realty case establishes that a public agency's interest in the protection of its functions and of the public interest constitutes an "interest" for purposes of permissive intervention. As permissive intervention under Rule 24 rests on a "claim" while intervention of right is based on the narrower term "interest," it seems the interest which warrants permissive intervention should, if other requisites are satisfied, support the absolute right to intervene.

It has been suggested, however, that the terms "bound by the judgment" have a connotation of res judicata. ${ }^{70}$ If this be true, it seems to follow that the Government cannot intervene because, as it will not be represented in the proceeding, it will not, strictly speaking, be "bound by the judgment." But it has been indicated that the term "bound" is not to be construed strictly, even where private litigants are concerned. ${ }^{7}$ So far as governmental intervention is concerned, Florida $z$. Georgiz seems clearly to indicate that the requirement that an intervener be "bound by the judgment" means merely that the effect of the judgment would be prejudicial. It was argued in that case that the United States could not by the terms of the Constitution become a party to an original proceeding between states in the Supreme Court. In response to that argument, Chief Justice Taney declared:

"We do not, however, deem it necessary to examine or decide these questions. They presuppose that we are bound to follow the English chancery practice, and that the United States must be brought in as a party on the record, in the technical sense of the word, so that a judgment for or against them may be passed by the court. . . . ... In a case like the one now before us, there is no necessity for a judgment against the United States. For when the boundary in question shall be ascertained and determined by the judgment of the court, in the present suit, there is no possible mode by which that decision can be reviewed or reexamined at the instance of the United States. They would therefore be as effectually concluded by the judgment as if they were parties on the record, and a judgment entered against them." 78

76. 2 Míore's Federai Practice (1938) 2333.

77. United States v. C. M. Lane Lifeboat Co., 25 F. Supp. 410, 411 (E. D. N. X. 1938).

78. 17 How. 478, 493-494 (U. S. 1854). In United States v. Houde Eng. Corp., 9 F. Supp. 836, 839 (W. D. N. Y. 1935) the rule was stated as follows: "If it appeared from the petition that the interest of plaintiff in the suit were not properly represented and that a substantial loss would result to him upon his not being a party, the right to intervene would be absolute." 
The circumstances which so prejudice the public interest or functions of an agency as to bring it within the meaning of the phrase "bound by the judgment" will of course vary from case to case. The Realty case furnishes an example. Any order in the proceeding which would have enabled the debtor to adjust its obligations under Chapter XI of the Bankruptcy Act would conclusively have impaired the exercise of the SEC's functions under Chapter $X$. It would have had an equally conclusive effect upon the public investors in the debtor who would have been deprived of the beneficial protection of Chapter $\mathrm{X}^{70}$ And such a determination would have had a far reaching effect upon the general investing public for it would have been a substantial deterrent to relitigation of the appropriateness of a Chapter XI proceeding in similar circumstances. Considerations of this character have led a federal court to say that, while in this situation neither the state nor its citizens would be technically estopped by an adverse judgment:

"Nevertheless, the practical effect in that event would be prejudicial, and might substantially conclude further litigation, even though against other individuals." 80

The element of inadequate representation remains for discussion. As intervention of right proceeds from the premise that the proceeding may injure the applicant's interest unless he is heard, and tacitly assumes that he is either completely unrepresented or inadequately represented, the logic of intervention suggests a construction of Rule 24(a)(2) which embraces one who is altogether without representation. Such a construction does no violence to the terms of the Rule, which authorizes intervention "when the representation of the applicant's interest by existing parties is or may be inadequate." It has been said, however, that this

79. If, for example, a plan should be promulgated in a Chapter XI proceeding which authorized an exchange of debentures for preferred stock, and a subsequent, more comprehensive reorganization were then held under Chapter $\mathrm{X}$ in which the SEC attempted to place those creditors who took preferred stock on a par with other creditors, the Commission might be faced with a conclusive finding that the exchange was fair. Compare Stoll v. Gottlieb, 305 U. S. 165 (1939).

80. Percy Summer Club v. Astle, 110 Fed. 486,488 (C. C. D. N. H. 1901). United States v. California Coop. Canneries, 279 U. S. 553, 556 (1929) arose out of a consent decree in a suit by the United States against certain packers. The canneries later sought to intervene on the ground that the decree prevented a packer from making contractedfor purchases. Intervention was denied. Commenting on this case, 3 OHlinger, Federal Practice (1939) 391 states: "It remains to consider whether the facts of this case would have satisfied subdivision (a) clause (2) of the present rule . . . As it was alleged that the consent decree 'interferes with the performance . . . of a contract' made with intervenor, a strong argument can be made that he would have an absolute right of intervention under the rule . . ." See also United States v. C. M. Lane Lifcboat Co., 25 F. Supp. 410, 411 (E. D. N. Y. 1938). 
language refers to the class actions provided for in Rule 23(a), ${ }^{81}$ which is likewise couched in terms of "adequate representation." 82 It is true that critics of the prior practice, in discussing "adequate representation," were chiefly concerned with the status of bondholders, creditors and stockholders in reorganization proceedings and the injuries that often flowed from use of the fiction that they were "adequately represented" by the trustee, directors or receiver. ${ }^{83}$ But 24 (a)(2) exhibits no intention to remedy these evils for it employs a formula - "inadequate representation" - that may still be satisfied by the very fiction which gave birth to these abuses. Moreover, the above classes - and these classes are most frequently said to be "adequately represented"84 - fall squarely within the terms of $24(a)(3)$ in that they may be "adversely affected by a distribution of property in the custody of the court". Hence to confine 24(a) (2), which purports to confer an additional right of intervention, to inadequate representation in a "class" situation is in practical effect to transform it into a more limited and consequently meaningless restatement of 24(a) (3). ${ }^{85}$ Even if inadequate representation in a non-class situation was not within the intent of the framers, it is nevertheless necessary to give effect to the broad language of the rule unless it can be shown that the framers, if they had contemplated the contingency, would have so varied the comprehensive language "as to exclude it from the operation of the" Rule. ${ }^{86}$ Finally, as a broader construction of "inadequate representation" preserves for the government its right to obtain relief against an otherwise remediless injury, it is favored by the moving principle of intervention practice and the explicit provision that the Rules are to be construed so as to do justice. ${ }^{87}$

\section{CONCLUSION}

We have seen that the threatened destruction of administrative functions on constitutional grounds, often accompanied by potential injury

81. 2 Moore's Feneral Practice (1938) 2333, n. 1. Mfoore cites no authority for this statement.

82. Federal Rules Crv. Proc. 23. "Class Actions. (a) Representation. If persons constituting a class are so numerous as to make it impracticable to bring them all before the court, such of them, one or more, as will fairly insure the adequate representation of all may, on behalf of all, sue or be sued, when . . ."

83. Moore \& Levi, stpra note 4 , at $596,600,604$.

84. Id. at 592 .

85. Should it be desired to retain the judicial power to prevent each of a thousand creditors from filing his pleading in the action, a qualification may be read into 24 (a) (3) to the effect that one who is adequately represented is "not adversely afiected by a distribution of property in the custody of the court." Cf. 3 Oeminger, Fenzral. Practice (1939) 410.

86. Puerto Rico v. The Shell Co., 302 U. S. 253, 257 (1937).

87. Fed. Rules Crv. Proc. 1: ". . . They [the rules] shall be construed to secure the just, speedy, and inexpensive determination of every action." 
to the public interest, confers standing to intervene upon a governmental agency. The Realty case established that an agency has standing to protest against a statutory interpretation which will impair its functions and deprive the public of protection. The SEC might with equal logic urge that investors may be deprived of safeguards and the Commission of a chance to function in their behalf by a certain construction of a statutory term such as "security." It might well argue that effectuation of the policies of the Securities Act required it to devise a series of safeguards for investors. As regulation narrowed the areas of chicanery and fraud, promoters were quick to devise artifices which superficially bore no resemblance to traditional "securities." Effective regulation demanded an expansion of the orthodox "security" concept, ${ }^{88}$ and administrative experience charted the course of expansion. Thus arose safeguards and functions which the SEC might by intervention seek to protect. Against this it may be urged that the safeguards and administrative functions in the Realty case were explicitly spelled out by stattite, whereas the question whether the term "security" affords a foundation for a similar administrative structure is purely a matter of construction. But the presence of safeguards and functions in the Realty case likewise turned on a question of construction, i.e., whether Chapter XI had been devised for the reorganization of publicly held corporations. And the SEC was permitted to intervene because, assuming its position that Chapter XI was unavailable for such purposes to be well taken, an impairment of its functions and the public interest through continuance of the Chapter XI proceeding would follow. In this light, the fact that administrative safeguards may be without foundation if the agency's interpretation of the term "security" be erroneous is not controlling.

The public has an interest in availing itself of administrative experience when a private suit tests a carefully wrought administrative policy. And the agency itself may in a real sense claim that a decision which destroys a particular administrative structure will result in an impairment of its functions. It does not follow that administrative agencies may conjure powers out of thin air, for the final power to determine whether the statute supports the administrative structure is lodged in the courts. But in making that determination, courts should hear an agency

88. See Securities \& Exch. Comm. v. Universal Serv. Ass'n, 106 F. (2d) 232 (C. C. A. 7th, 1939) ; Securities \& Exch. Comm. v. Crude Oil Co., 93 F. (2d) 844 (C. C. A. 7th, 1937). For similar problems with reference to the term "sale" see Securities \& Exch. Comm. v. Starmont, 31 F. Supp. 264 (E. D. Wash. 1940). To require the legislature to define in more exact terms the evils sought to be prevented is to leave the door open to fraud. Having indicated the general policy in sufficient detail, the legislature may properly leave some room for the free play of informed administration. Administrative flexibility is required to cope with unforeseeable subterfuges. Cf. Redmond \& Co. v. Michigan Secur. Comm., 222 Mich. 1, 192 N. W. 688 (1923) ; Bartlett Frazier Co. v. Fyde, 65 F. (2d) 350 (C. C. A. 7th, 1933). 
when it believes that a given construction of a statute which it administers impairs its functions or runs counter to the public interest.

It has been the purpose of this Article to show that nothing in Rule 24 stands in the way of a reconciliation between administrative needs and traditional intervention practice. The Federal Rules are to be viewed in the perspective of history. They are a step in the long process that has been steadily transforming procedure from the rigorous exercise of a scholastic into a flexible medium of justice. As the latest expression of that liberalizing movement, designed to clarify and restate the best tendencies in procedure, the Rules should not be employed to force federal practice into a rigid mold. A purely verbalistic approach to construction must tend to defeat the whole purpose of the restatement. If Rule 24 is interpreted to deny an agency the right to be heard when it believes that a construction of a statute which it administers impairs its functions or runs counter to the public interest, an approach is taken which finds no warrant in the cases, ignores the vital needs of government and departs from the rationale of intervention practice: the prevention of injury which may result to third persons from the use of judicial process. 